\title{
Case Study
}

\section{Exposure to Unconventional Outdoor Media Advertising}

\author{
Wegig Murwonugroho $^{1 *}$ and Gregoria Arum Yudarwati² \\ ${ }^{1}$ Visual Communication Design Department, Art and Design Faculty, Universitas Trisakti, Jakarta 11440, \\ Indonesia \\ ${ }^{2}$ Communications Department, Social and Political Sciences Faculty, Universitas Atma Jaya Yogyakarta, \\ Sleman 55281, Indonesia
}

\begin{abstract}
This study is aimed at examining unconventional outdoor media advertising, the visualization structure of advertisements, and how messages are displayed. The research method used was Norman Fairclough's critical discourse analysis, which involved the following: a) a text analysis, identifying the advertising visual structure; b) an analysis of discourse practices, which comprises how texts are narrated, modelled, produced and consumed; and c) a social practice analysis, which links advertising ideas and urban cultures. The research involved 30 respondents consisting of students, lecturers, and employees of Universitas Trisakti in a focus group discussion (FGD) to obtain public perceptions of visual attractiveness. Outdoor media advertising is attributed to the development of creative, short, readable messages, with simple visual structures that enable reading patterns from left to right or top to bottom.

Based on observations of three research samples, it was found that there were novel

ARTICLE INFO

Article history:

Received: 14 October 2019

Accepted: 26 May 2020

Published: 25 December 2020

DOI: https://doi.org/10.47836/pjssh.28.4.50

E-mail addresses:

wegig_besar@yahoo.com (Wegig Murwonugroho)

arum.yudarwati@uajy.ac.id (Gregoria Arum Yudarwati)

*Corresponding author ideas regarding outdoor media advertising creative strategies, namely, a) the novelty of advertising a new visual element structure by reversing outdoor media design principles; b) the intentional convention of reversed messages having evoked a more interacting public response; and c) advertising with sociocultural narrative content through the provision of advertised commercial products and services. The findings in this study
\end{abstract}

ISSN: 0128-7702

e-ISSN: 2231-8534 
show that there is a longer exposure level to unconventional outdoor media; therefore, the public's goal is to interpret the message delivered. Unconventional advertising is the new orientation of communication strategies. The findings in this study have practical implications in arrangement of visual structures to become more interactive.

Keywords: Critical discourse analysis, exposure, unconventional outdoor media, urban culture

\section{INTRODUCTION}

Outdoor media is a form of advertisement conducted in public space, although its existence does not necessarily repudiate the increasing use of social media. Its popularity tends to move from one place to another, and it is not always expected such advertisements be displayed on electronic media devices. At some point, people get bored of staring at the monitor or smartphone screen, particularly when it starts to hurt their eyes. Sometimes, the outside space seems to be more prevalent and attractive. This is the starting point for advertisers; therefore, they need to take advantage of this opportunity. Outdoor media complements or is an alternative for conveying commercial and social messages in public spaces.

Public spaces are defined as areas where there are usually gatherings such as crossroads, parks, markets, and family recreation facilities. Thus, traffic congestion tends to be a potential public space for advertising because it affords people more time to explore the messages on billboards, and posters on both sides of the road. Traffic congestion is a routine that is frequently experienced by urban communities (Babu, 2017).

Advertisers are always faced with the struggle for public attention, and they try to approach areas where the populace is concentrated. Moreover, they also respond to the trends of the various activities in contemporary urban society with characteristics such as novelty and the tendency to break free from old boring patterns. According to Struppek (2014), people are usually attracted to new and unusual visual designs. Therefore, there is a need for ideas that tend to make the advertisement more appealing, thereby attracting public attention (Buljubasic, 2015; Buljubasic et al., 2016).

The visual structure of each ad is basically hierarchical; however, some of its elements need to be highlighted, while some are intentionally not promoted. In outdoor media, the difference in proportion refers to the design principle, which is always based on a precise and legible message. Such ads are also positioned to dominate the wording in the visual appearance. Similarly, the pattern of reading needs to be reasonable, either from left to right or from top to bottom (Shareef et al., 2019).

Presently, people live in an information world. However, this causes individuals to feel that they are "overburdened with information," particularly when dealing with messages on commercial advertisements, which leads to the training of modern consumers on how to avoid and ignore such conventional communication. 
In 2018, three forms of outdoor media advertising were initiated in Jakarta: 1) the visualizing of texts with long narratives, 2) imagery rotated 180 degrees, and 3 ) the use of ornamental materials not commonly used in advertising. This unconventional visual approach raises curiosity as to whether the anti-mainstream creative strategy is attractive to consumers. In contrast, there are certain questions in accordance with the exposure to outdoor media, which tends to lead to unconventional advertisement visualization, which the writer needs to explore in-depth.

\section{Unconventional Advertising}

According to Buljubasic (2015), unconventional advertising is able to provide an alternative novelty of ideas in the competitive labour market, where consumers are faced with numerous advertisements that tend to be similar. Such advertising delivers messages in an unexpected form and even entertains people who are exposed to it. The term unconventional refers to curiosity, instability, inventiveness, originality, ordinariness, or alternation (Buljubasic, 2015). Therefore, unconventional advertisement comprises unusual, non-traditional, innovative, and inventive means, methods and strategies involved in promoting brands, products, and services (Jurca, 2010).

Unconventional advertising is able to protect penetrators from commercial messages with which they are bombarded daily (Buljubasic, 2015; Jurca, 2010). This occurs because unconventional advertisements are unpredictable, often captured in locations and situations where they are not expected to be advertised, as well as in conditions where their guards are let down. In addition, unlike traditional advertising, unconventional advertising does not use persuasive messages that try to convince an audience to purchase goods or commodities; instead, it is aimed at creating lasting impressive images of promoted brands in the subconsciousness of customers (Jurca, 2010).

This type of advertising emerged with the development of unconventional marketing, which is also referred to as guerrilla marketing (Buljubasic et al., 2016; Hutter \& Hoffmann, 2011). This term was introduced by Levinson in 1984 and is defined as a type of marketing that places more emphasis on artistry rather than on money (Cova \& Saucet, 2014). Unconventional marketing requires exceptional creativity and innovation to attract the public. It utilizes surprising, catchy, funny, witty, and spectacular effects as some of its strategies (Buljubasic et al., 2016). The essence of this approach is that it seeks to create surprises in unexpected situations and places to attract public attention and increase publicity. This concept has led to the emergence of unconventional advertising practices.

Several approaches are involved in classifying unconventional advertising. Kaikati and Kaikati (2004) identified six techniques: 1) viral marketing, 2) brand influencers, 3) celebrity marketing, 4) baitand-tease marketing, 5) marketing video 
games, and 6) marketing pop and rap music. They are categorized into stealth marketing types. This strategy relies on the power of oral communication, and it is often referred to as a form of "undercover," "covert," or "hidden" marketing (Jurca, 2010). Furthermore, messages are conveyed in disguise and carried out in implicit and undetected ways. Moreover, in accordance with the placement area, it is a system of advertisement that tends to be conducted anywhere, such as in taxis, buses, elevators, and even bathroom stalls (Jurca, 2010). The categorization of this type of advertising varies; however, all techniques employed are intended to increase publicity.

\section{Advertising Exposure}

Advertising has been a part of urban culture for some time. Urban culture involves the way of life of modern society living in cities and comprises the norms, value systems, and social practices adopted by the community as a whole. Syah (2013) argued that the success of an urban civilization was directly linked proportionally to the competence and educational level of the community. Thus, the urban cultural patterns of a society can be formed from media that is consumed widely, including advertising.

The success of an advertisement can be measured by its visual impact or its exposure. The term exposure is derived from the word expose, which means analysing something to be clear. In certain contexts, it means showing off and leaving unprotected, exposed, and unfolding. Therefore, "advertisement exposure" simply implies the publicity of advertising media to create an impact.

The media has an influence on the knowledge, attitudes, and behaviour of the audience, while its impact depends on the number, type, and duration of its exposure to the public (Tamam et al., 2009). The duration of advertising exposure is the most influential element in the successful conveyance of the messages to viewers. Subsequently, further impacts are identified in the public's understanding of the advertisement, which also causes the media to boost brand awareness by creating a one-way communication link between potential consumers and advertisers (Ahmad et al., 2017). This is mainly because the lingual and para-lingual expressions of advertisers are not always effective. However, people's behaviour towards shopping is an indication of the success or failure in selling commodities (Naderi \& Yazdi, 2018).

\section{Unconventional Outdoor Media in the Midst of Urban Communities}

Go-Jek is a multiservice technology platform that offers various services, such as transportation, payment of pensions, and food delivery. This multiservice platform displays outdoor media advertisements at locations where traffic often occurs. The ads are visualized with lengthy discernible narrative text elements and the use of relatively small fonts, as shown in Figure 1. Generally, this visualization differs diametrically from that of outdoor media, which uses short text that is easier to 
read. Furthermore, its image dominates the advertising media. The appearance of small font sizes and lengthy sentences as in newspapers arouses curiosity as to whether the public tends to read until the end of the sentence.

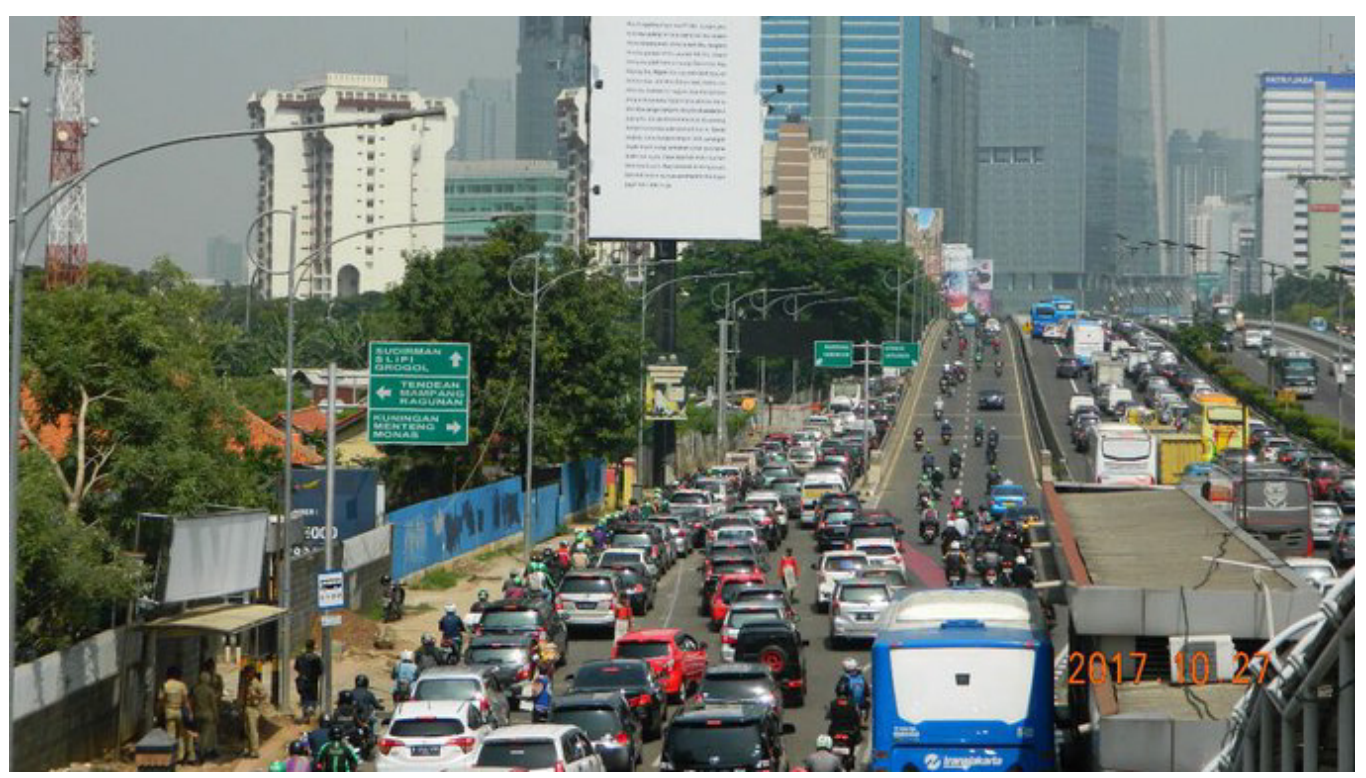

Source: https://marketeers.com/wp-content/uploads/2017/11/Billboard-Kuningan.jpeg

Figure 1. Advertising billboard with non-colourful, white background. The media is filled with small sized text, which is different from the usual outdoor advertising practice of using a minimum number of words.

The second example is the Lazada outdoor media, which also displays advertisements with unusual visual styles. It is displayed on a billboard by rotating the visualization at 180 degrees, as shown in Figure 2. Therefore, this affects the reading position of the reader. In principle, texts are read from top to bottom; however, this technique is upside-down.

The third sample is the complimentary support offered by Go-Jek to Tolak Angin, a product of "anak bangsa". The visualization uses an imitation of a fresh flower arrangement, as shown in Figure 3. Generally, advertising sentences on billboards are written proportionally with characterized and neat fonts. However, this ad uses a distorted print type, similar to flowers constructed by craftsmen, which generally do not understand the aesthetics of the font face. This artificial flower looks colourful and fresh and resembles a congratulatory wreath attached to a Styrofoam board. 
Unconventional elements are popular on social media with an intense desire to determine their impact on the reading exposure of the target audience. This discovery reinforces the theory that the novelty of visualization encourages more viewers to read (El-Dali, 2019; Negm \& Tantawi, 2015). Furthermore, there are several questions regarding the appearance of unconventional outdoor media. a) How is the structure of the visual novelty constructed? b) What is the public's response to the advertising designs used? c) How does its ideology influence urban culture? These three formulations are the subject of this research in accordance with the critical discourse analysis (CDA) method.

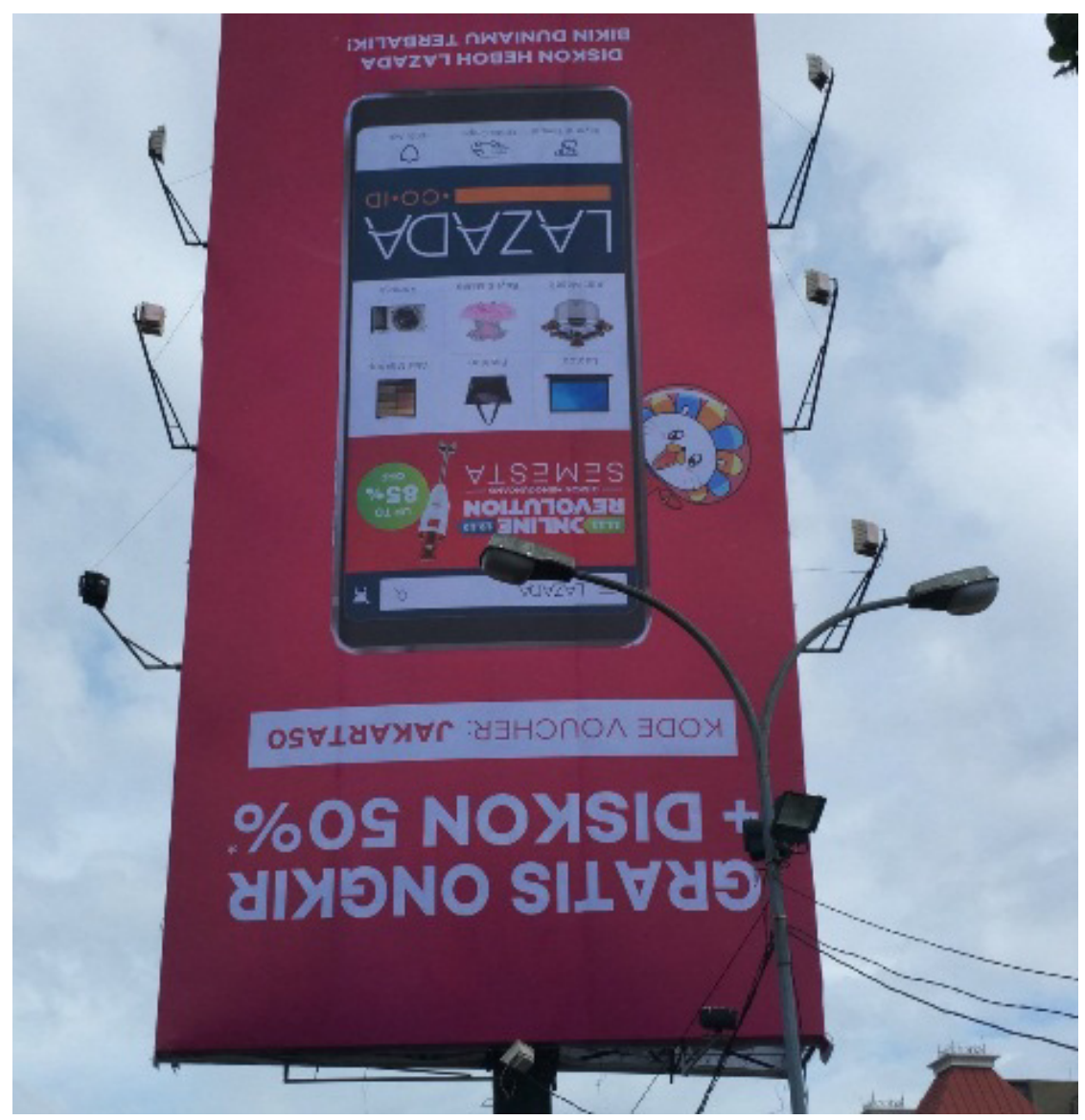

Source: https://s.kaskus.id/images/2018/09/21/8114157_20180921034704.jpg

Figure 2. Advertising billboard with $180^{\circ}$ rotation visual. Notice the advertisement's word play; $50 \%$ shipping rate, not $50 \%$ of the product's selling value 


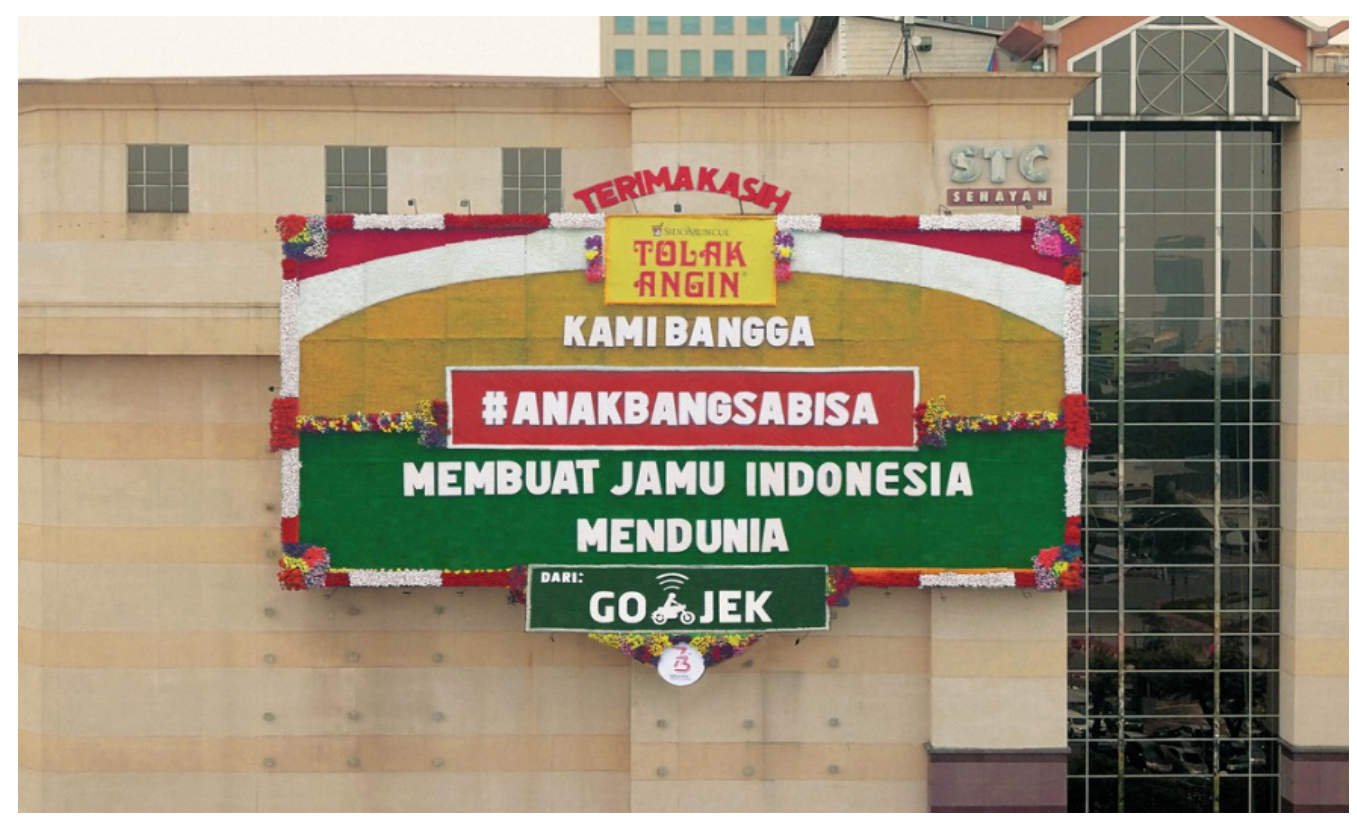

Source:http://strg.citrapariwara.org/2018/files/04.08.40/73_Kopiko-Tolak\%20Angin-Kapal\%20ApiAthletes $\% 20-\% 202 \% 20-\% 2010 c . j p g$

Figure 3. Advertising billboard with an imitation of a fresh flower arrangement. Looking fresh while visually resembling the real thing, it is unconventionally not modern. Notice that the font used is not in accordance with its typeface.

\section{Aims of The Study}

This study was aimed at examining the advertising exposure of unconventional design in outdoor media advertisements. Based on previous studies conducted on exposure by employing critical discourse analysis, this study focused on three dimensions: (1) text analysis, (2) discourse practice analysis, and (3) social practice analysis. First, the study examined the text to understand how unconventional visual design was structured. Second, the processes of production, distribution, and consumption were analysed. Finally, this research reviewed how discourse events shaped the nature of discursive practice.

\section{METHODOLOGY}

Fairclough, as shown in Figure 4, represents the stages involved in the CDA method as follows: a) text analysis; b) analysis of discourse practices, which comprises how texts are produced and consumed; and c) social practice analysis. The first stage, text analysis, examines structured unconventional visuals displayed by outdoor advertising media. In the second stage, an analysis of the discursive practices reviews how an advertisement is placed and the public's response to it. In the final stage, social phenomena that serve as narratives in advertisements affect cultural patterns, unless there is an ideology that inadvertently 
and continuously penetrates the public. The entire analysis leads to the concept of how unconventional billboards are constructed and patterned and the individual or organization involved (Fairclough, 2000).
All analyses serve the purpose of exploring the relations among language, ideology, and persuasive power to encourage people to buy or use the services advertised.

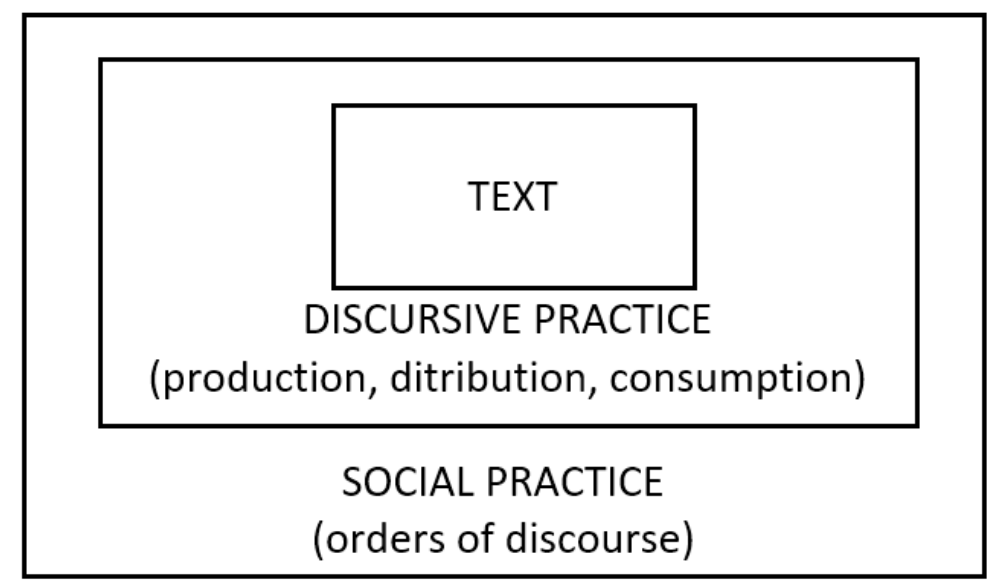

Figure 4. Fairclough's three-dimensional model (Fairclough, 2001)

This research examined the character of unconventional designs in three different case studies. The first was Go-Jek outdoor media advertising, as shown in Figure 1, which employed a narrative text design in the form of lengthy writing. The second case was Lazada's online shopping, which employed an advertisement design with inverted visualization, as shown in Figure 2. Third, the complementary support by Go-Jek to Tolak Angin, as shown in Figure 3 , employed the visualization of artificial flowers. The selection of the three ads based on these criteria was intended to suit urban communities that tended to be attracted to new, fresh, and out-of-the-box designs
(Miller \& Nicholls, 2013). In addition, the three outdoor media advertisement samples were deliberately chosen due to the phenomenal conversations on social media about them, which was a novelty of the contemporary design.

This research involved 30 respondents consisting of students, lecturers, and employees of Universitas Trisakti in a focus group discussion (FGD). During the dialogue, three advertisement samples were projected onto a screen. In deeper dialogue, it was found that visual attractiveness, persuasive aspect, and the meaning of it inspire urban society's behaviours. The purposive sampling method was used to 
obtain data from 30 participants living in an urban area with a high level of traffic congestion in Jakarta. They were selected based on two criteria, namely, visual exposure to outdoor media advertising and the message conveyed in the advertisement.

\section{RESULTS AND DISCUSSION}

According to Hutter (2014), the use of unconventional advertising techniques has a more substantial impact on consumers' perceptions either in the form of behaviour or attention than on conventional advertisement. An in-depth explanation of the results from the Fairclough critical discourse analysis is described in several subsections below.

\section{Text Analysis}

\section{Go-Jek Outdoor Media (The Media} is Fulfilled with Text). In the concept of structural analysis, outdoor media advertising displays unconventional visuals in an organized and orderly manner, as shown in Figure 1. The appearance of this billboard media utilizes the visualization of ads with lengthy writing and small font sizes, deliberately designed to offer its effect on people. Billboards often show more colourful images, and this media involves black writing on a white background.

In this research, the most striking feature of this ad was the visualization of text ads without images. Instead of using colours and shapes, it used descriptive narrative black and white text, with small font sizes. A billboard unit contains full text without any trinkets, and this is a point of irregularity.
Structurally, the simplicity of colours allows for the text to be more legible.

\section{Lazada Outdoor Media (The Visualization}

Rotated $180^{\circ} /$ Reverse). This billboard offers unique features for its readers, and it is rotated 180 degrees, as shown in Figure 2. The letters of the alphabet are usually read from left to right and sequentially from top to bottom; however, the reverse is the case with this ad. The billboard not only reverses the position of the image but also changes the fonts in the ad. Structurally, a short font type with striking numbers is readable even when it is rotated.

\section{Tolak Angin Outdoor Media-visualization} of a Garland or Wreath. This outdoor advertising media utilizes artificial fresh flowers aimed at changing the old traditions. Generally, outdoor media uses lighted billboards, simple drawings, and standard font faces; however, in this case, the form of visualization is set with a variety of "fresh" flowers, even though they are truly artificial. This adjustment certainly satisfies the tastes of urban people because they prefer antimainstream matters, even when they are brief. However, the features of advertising media in urban areas need to be designed in accordance with the rural environment (Anzabi, 2016). Therefore, colourful flowers offer a lively, natural, and fresh appearance, thereby attracting the attention of people to read the messages, even though the flowers are artificial.

Structurally, it is impossible to mount outdoor media of massive size placed in 
a high position because of its tendency to be damaged in the long term; therefore, outdoor media tends to fund the construction of visual elements. The similarity of work details with congratulations boards sometimes fails to heed the type face font proportion, which reinforces the identity of the congratulatory wreath made by craftspeople, who sometimes lack aesthetic value sensitivity.

\section{Synthesis of Text Analysis}

These three outdoor advertising media show the structure of creative visual elements, which are called unnatural, odd, or unconventional by contrasting and reversing the establishment of design principles.

\section{Discourse Practice Analysis}

The focus in the discussion of discourse practice analysis is on the ways to communicate the contents of outdoor advertising media to promote products. The following findings are the results of interviews with 30 respondents about the three advertisement samples.

As shown in Table 1 and Figure 5, the majority of respondents perceived the fulltext visualization of Go-Jek as the most attractive, followed by Tolak Angin's flower arrangement and Lazada's rotated visual as the least attractive. However, Lazada was thought to have the most persuasive strength with its "discount" tag.

With discourse practice analysis, it can be synthesized that the basis for advertising design is an orientation toward public interaction. People are encouraged to tilt or shake their head, made to stare at a billboard with unusual texts, and stimulated to question and find the answer on the billboard.

The selection of visual style, content information, and diction in the above samples has succeeded in attracting people's attention to advertising messages. Based on research participants' responses, on several occasions, the media breaks people's expectations. This psychological shock is the main target of advertisers, making their messages more memorable and impactful. Turhan and Okan (2017) found that the use of rhetorical language and the right timing to use it were very potent in changing someone's understanding of social problems. Therefore, the advertising samples above mainly discuss the sociological aspect of human activity.

Table 1

Public response to the attractiveness and persuasiveness of advertising media samples

\begin{tabular}{lll}
\hline Advert. samples & Attractive-ness & Persuasive-ness \\
\hline Sample 1 (Go-Jek) & 16 & 9 \\
Sample 2 (Lazada) & 3 & 16 \\
Sample 3 (Tolak Angin) & 11 & 5 \\
\hline TOTAL & 30 & 30 \\
\hline
\end{tabular}




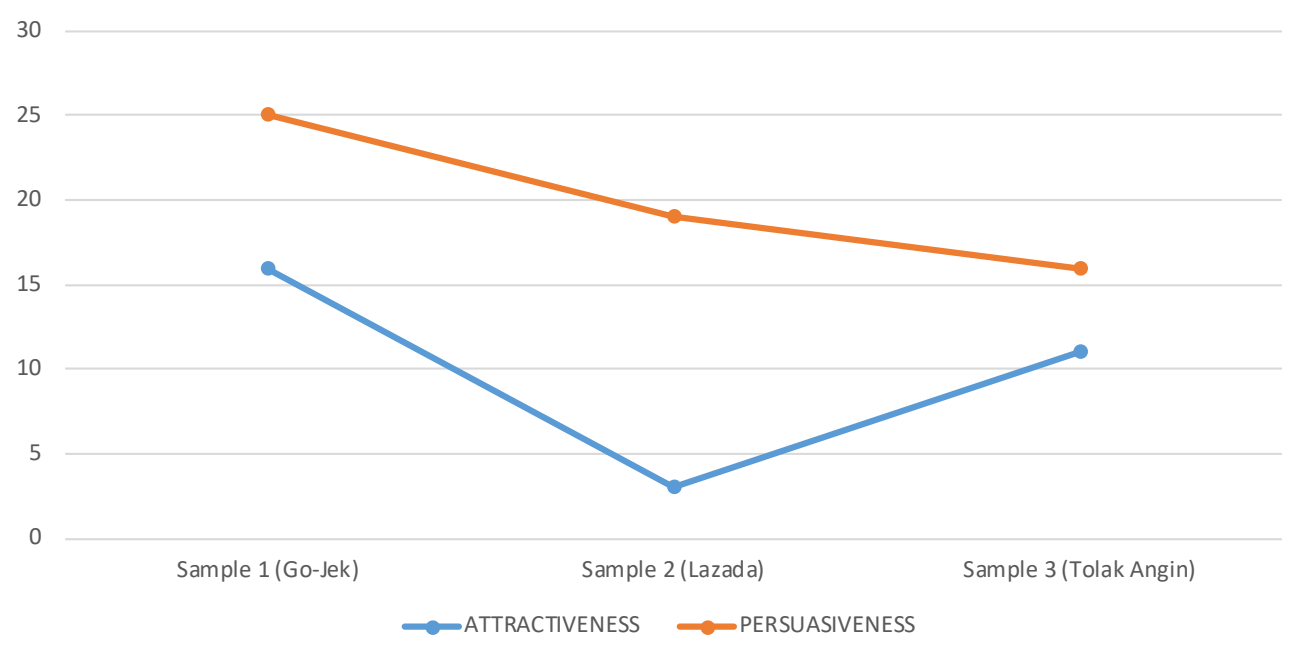

Figure 5. The public response to advertising media

\section{Go-Jek Outdoor Media (The Media Filled} with Text). This advertisement is started by asking questions such as "Still stuck on the road?" Therefore, when the reader comes across the next paragraph, they are presented with various pieces of important information regarding transportation and traffic. The presence of this flowing and easily understood narrative becomes an interesting reason for them to read until the end.

Observation showed that the public response to Kompasiana, Instagram, Facebook, and other social media platforms in accordance with advertisements provided a longer reading time due to the opportunity to be able to read the entire narrative of the text from beginning to end. The feeling of curiosity used to determine the manuscript status became a public stimulus.
This finding also reinforced the results of Moldovan et al. (2019), which stated that creativity was not enough to stimulate the response of urban society. An advertisement is required to fulfil the truth of information, which is the legitimate demands of the logical thinking of contemporary urban society. Terkan (2014) also stated that it was important to add persuasive nuances by manipulating the values and desires of potential customers.

\section{Lazada Outdoor Media (The Visualization} Rotated 180\%/Reverse). This advertisement is a billboard rotated 180 degrees, which looks reversed, with the provision of information on the products offered on the online-based app store. The visualization of an inverted cell phone with a 50\% discount promotion shows a low price moment that only lasts for a short time. Therefore, aside 
from being interested in large discount framing (McKechnie et al., 2012), many viewers try to tilt their heads to obtain information, which is considered unusual or not routinely informed.

The public was initially tempted by looking at the text "Free Delivery and 50\% Discount," which was a novelty for reading unusual advertisements. The visualization of text and images rotated 180 degrees tended to attract the public. Respondents were able to read the reversed text because the font types dominated the media space.

In an effort to understand advertising messages, the public was deliberately invited to partake in motor activities by moving their heads. According to Steinhart (2012), this method is called an activation technique, which requires the reader to perform physical or mental activity. However, the results of the interpretation of the subject's response showed that the uniqueness of this media was only limited by the direction matter, with the meaning ultimately focused on a uniform conclusion.

\section{Tolak Angin Outdoor Media-visualization} of a Garland or Wreath. Moreover, on the third billboard media, outdoor advertisements are displayed with fresh flowers, and the billboard consists of text that symbolizes flattery and appreciation from an online-based transportation app company such as modern herbal medicine. Based on the interpretation of the subject's response to the billboard, it is concluded that it becomes a starting point for considering an advertisement's level of prevalence, which has exceeded general limits.

\section{Synthesis of Discourse Practice Analysis}

Based on interviews with 30 participants, $57 \%$ considered Go-Jek advertisements, which prioritized text rather than visuals as the most attractive advertisements, followed by Tolak Angin Outdoor Media with wreath visualization (27\%) and Lazada with $17 \%$.

In the discourse practice analysis, it is synthesized that the basis of advertising design is to create an interactive channel with the public. The public is invited to tilt their heads, stare longer with unusual reading methods, and raise new questions with the answers obtained by paying more attention to the advertisement. According to research carried out by Kenechukwu et al. (2013), advertisements are actually unnecessary, time-wasting, and misleading, with invalid information. However, the visual design, content, and choice of diction in the advertisement are used to attract people's interest in reading the presented messages.

\section{Social Practice Analysis}

Go-Jek Outdoor Media (The Media is Fulfilled with Text). Go-Jek's outdoor advertisement is used to minimize the increasingly widespread infrastructure development in Jakarta and the number of private vehicles. This advertisement is a satire criticism for the majority of road users who are reluctant to use public 
transportation. In fact, the use of private vehicles has drained energy, time, and money associated with parking fees. "Still stuck on the road? Online transportation is your solution," this is the initial teaser of advertising messages that offers a solution by inviting users to partake in a more frugal lifestyle. The nature of advertisements generally manipulates opinions and behaviour (Hayko, 2010) because of their social practice and is herded to one of the providers of online transportation (which is Go-Jek). As a form of social practice, ideological advertising has played the human subconscious by bringing up a dialogue that adopts social phenomena.

In this first billboard media appearance, the written content is a description of the various activities that are carried out, assuming that the public arrives at the destination on time. The target audience is also asked to anticipate their happiness, assuming that they returned home from work early. Advertising has the power to make the public continue to utilize online transportation services. Therefore, Mandiri E-money, BCA flash, and other cards need to be filled with sufficient funds.

\section{Lazada Outdoor Media (The Visualization} Rotated $180^{\circ} /$ Reverse). In accordance with billboards with reversed content visualization, the public feels remorseful, assuming that they fail to tilt their heads to obtain the information displayed. Moreover, there is a persuasive copy, such as "Free Delivery, 50\% Discount". Indeed, all advertisements refer to the same basis of manipulating consumer behaviour (Frolova, 2014). However, in this case, advertisements with reversed visual designs have succeeded in manipulating consumer behaviour.

The advertisement placed by Lazada is displayed and rotated 180 degrees. Ethically, it needs to be fair with regard to other brands; therefore, the chosen strategy is to perform billboard visualization. Through these patterns, the public is unconsciously led to possess consumptive and hedonic patterns (Gupta et al., 2013). In this social practice, it is seen that the ease of buying goods online is utilized by this advertisement, which affirms the legitimacy of public submission to power under online purchasing control.

\section{Tolak Angin Outdoor Media-visualization} of a Garland or Wreath. The third media billboard is an outdoor advertisement that uses fresh flowers. This accentuates the appreciation of the herbal brand, which despite its global and modern reputation, tends to use traditional Indonesian natural ingredients.

This advertisement coincides with Indonesia's Independence Day. Therefore, Go-Jek utilizes the momentum and the spirit of nationalism, supported by the visualization of garland to produce a more creative advertisement. This is an appropriate and conceptual reason. However, the majority of the public is not able to relate to this event (Okazaki et al., 2010). This social practice is understood by the community, which is limited to the perception that life is facilitated by the presence of Go-Jek as a means of transportation, order delivery, and 
payment. The idea of an artificial wreath as a congratulatory statement is a sign of Eastern cultural identity that produces public sensations in the midst of urban culture.

\section{Synthesis of Social Practice Analysis}

According to Lim (2014), physical public space has become an interdependent dimension with social movements. The findings in the analysis of social practice at the same time confirm the research of Nowghabi and Talebzadeh (2019), which stated that in urban society, billboards and visualization caused confusion in the minds of the community. This is considered a nuisance when viewed from a certain angle, and it is also called double disturbance. However, in terms of the ease of processing information, this kind of advertising method does not psychologically include interference. It is also worth considering the results of Cronin's (2006) research, which confirmed that outdoor advertising played an important role in adjusting to the urban rhythm and its society. The rhythm of the target urban society is typical of jobs and activities that are innovative, addictive and consumptive. In the FGD deeper dialogue session, we found the following reactions (Table 2) in each sample.

Table 2

Public interpretations of advertisement samples

\begin{tabular}{ll}
\hline Advertisement sample & Meanings interpreted \\
\hline Sample 1 (Go-Jek) & $\begin{array}{l}\text { Understanding the benefit of online transportation but } \\
\text { realizing its relatively costly price }\end{array}$ \\
Sample 2 (Lazada) & $\begin{array}{l}\text { Understanding the advertisement's word play; } 50 \% \\
\text { shipping rate, not } 50 \% \text { of the product's selling value }\end{array}$ \\
Sample 3 (Tolak Angin) & $\begin{array}{l}\text { Understanding the meaning of artificial fresh flowers } \\
\text { as a national congratulatory icon, used in this case for } \\
\text { inventing traditional jamu }\end{array}$ \\
\hline
\end{tabular}

Lazada and Go-Jek offered solutions by presenting the problems faced by ordinary people. This is in line with Abdelaal and Sase's (2014) research, which stated that advertisers always proposed a thesis to acquaint viewers with the necessary information. After the sensation is considered to appear, the advertiser provides an antithesis in the next sequence. This kind of marketing strategy is widely used, and subsequently, the problem that arises is the different ways in which to lock public attention on the product by using unusual visual displays.

Practically, the formation of a new synthesis of the social practice analysis 
presented to the public is viral in the community because the closeness of the issue tends to ease the understanding of advertisements.

This finding is similar to the research conducted by Kaur et al. (2013), which stated that advertisers tried to manipulate the lifestyles of urban communities in certain contexts. They tended to form a new construction of knowledge and trust in shopping, communicating and transporting with the conclusion that people's minds are controlled by advertising using language. However, this research concludes that people's minds are formed and reconstructed through visuals.

From this analysis, it is seen that the narrative of advertising in the context of social culture is a solution used to respond to public needs. Furthermore, it examines the problems that require the ease of transportation services, as well as commercial purchasing systems, which are easy, practical, and inexpensive. Finally, the public has been made aware of the importance of advertised commercial products and services. Therefore, there is a dependence on a capitalist system, where convenience is easily obtained through payment. Furthermore, the marginal people still jostle using mass transportation and are still not aware of being vulnerable to being fooled by online shopping services.

\section{CONCLUSIONS}

Critical discourse analysis is chosen because it does not limit the advertisement study to visual signs and covers its meanings and interests behind each creative process. Advertisement has the ideological purpose of not only selling and attracting attention to products/service but also changing people's behaviour in using such products/services. Urban society has a certain tendency to use online systems for daily needs. People tend to be willing to spend money for the comfort provided by online systems, even if it may cost them more.

Visual irregularities in unconventional outdoor advertising media show that the public tends to stare longer while interpreting the message. The unconventional approach in designing advertisements is able to uncover consumers' reluctance to look at advertising media and at reading the message to the end. This success occurs because the visualization of advertisements has an unexpected nature, and it is present in locations and situations where they do not expect or suspect the awkwardness of the advertisement visualization. Generally, conventional advertisements try to convey persuasive messages and try to convince the audience to buy or use the services offered. This is in contrast to the visualization of the outdoor media advertisements that try to instil long-lasting monumental ideas in the minds of consumers. The public is invited to partake in dialogue with antagonistic text structures, stimulated to interact with some of their body movements, and to find solutions to public problems in the midst of urban culture.

An advertisement has also played on the public subconscious with a pattern related to capitalism in urban culture. It also has 
the power to make the public depends on its features, such as online transportation. Similarly, the ease of online transactions leads to consumptive patterns as the identity of urban cultural lifestyles.

\section{ACKNOWLEDGEMENT}

We would like to thank the Dean of Art and Design Faculty, Universitas Trisakti and the Dean of Social and Political Sciences Faculty, Universitas Atma Jaya Yogyakarta, for supporting this collaborative study. We also share our gratitude to the Indonesia Advertising Association for their kind support. Last but not least, we thank advertising and communication students, who enthusiastically participated in this study.

\section{REFERENCES}

Abdelaal, N. M., \& Sase, A. S. (2014). Advertisement analysis: A comparative critical study. Advances in Language and Literacy Studies, 5(6), 254-259. doi: 10.7575/aiac.alls.v.5n.6p.254

Ahmad, N. S., Bakar, S. A., \& Musa, R. (2017). Exploring the roles of Social Media Content Marketing (SMCM) towards Return on Investment (ROI): A conceptual paper. Pertanika Journal of Social Sciences and Humanities, 25(S), 261-268.

Anzabi, N. (2016, December 27-29). The usage of urban furniture in city advertisement. Paper presented at the 4th International Congress on Civil Engineering, Architecture and Urban Development, Shahid Beheshti University, Iran-Tehran.

Babu, A. M. (2017). Study of urban cities traffic problems due to delay and overcrowding.
International Journal of Latest Engineering and Management Research, 2(8), 1-8.

Buljubasic, I. (2015). Impact of unconventional advertising on performance of cultural institutions in city of Osijek. Interdisciplinary Management Research, 11, 1097-1105.

Buljubasic, I., Ham, M., \& Pap, A. (2016). Factor influencing the implementation of unconventional marketing in cultural institutions, evidence from Croatia. Scientific Annals of Economics and Business, 63(2), 247-272. doi: 10.1515/saeb-2016-0120

Cova, B., \& Saucet, M. (2014). Unconventional marketing: From guerrilla to consumer made. In L. Moutinho, E. Bigné, \& A. K. Manrai (Eds.), The Routledge Companion to the Future of Marketing. New York, USA: Routledge.

Cronin, A. M. (2006). Advertising and the metabolism of the city: Urban space, commodity rythms. Environmental and Planning D: Society and Space, 24, 615-632. doi: 10.1068/d389t

El-Dali, H. M. (2019). The language of consumer advertising: Linguistic and psychological perspectives. Studies in Linguistics and Literature, 3(2), 95-126.

Fairclough, N. (2000). Critical discourse analysis. London, England: Routledge.

Fairclough, N. (2001). Language and power. London, England: Longman.

Frolova, S. (2014). The role of advertising in promoting a product. Kokkola, Finland: Centria University of Applied Sciences.

Gupta, A., Bansal, R., \& Bansal, A. (2013). Online shopping: A shining future. International Journal of Techno-Management Research, 1(1), 1-10.

Hayko, G. (2010). Effects of advertising on society. Hohonu, 8, 79-82.

Hutter, K. (2014). Unusual location and unexpected execution in advertising: A content analysis and 
test of effectiveness in ambient advertisements. Journal of Marketing Communications, 21(1), 33-47. doi: 10.1080/13527266.2014.970823

Hutter, K., \& Hoffmann, S., (2011). Guerrilla marketing: The nature of the concept and propositions for further research. Asian Journal of Marketing, 5(2), 39-54. doi: 10.3923/ ajm.2011.39.54

Jurca, M. A. (2010). The forms of unconventional advertising - a theoretical approach. Management and Marketing Journal, 2, 323-333.

Kaikati, A. M., \& Kaikati, J. G. (2004). Stealth marketing: How to reach consumers surreptitiously. California Management Review, 46(4), 6-22.

Kaur, K., Arumugam, N., Yunus, M. N. (2013). Beauty product advertisements: A critical discourse analysis. Asian Social Science, 9(3), 61-71. doi: 10.5539/ass.v9n3p61

Kenechukwu, S. A., Asemah, E. S., \& Edegoh, L. O. N. (2013). Behind advertising: The language of persuasion. International Journal of Asian Social Science, 3(4), 951-959.

Lim, M. (2014). Seeing spatially: People, networks and movements in digital and urban spaces. International Development Planning Review, 36(1), 51-72. doi: 10.3828/idpr.2014.4

McKechnie, S., Devlin, J., Ennew, C., \& Smith, A. (2012). Effect of discount framing in comparative price advertising. European Journal of Marketing, 46(11), 1501-1522. doi: 10.1108/03090561211259952

Miller, B., \& Nicholls, W. (2013). Social movements in urban society: The city as a space of politicization. Urban Geography. doi: 10.1080/02723638.2013.786904

Moldovan, S., Steinhart, Y., \& Lehmann, D. R. (2019). Propagators, creativity, and informativeness: What helps ads go viral. Journal of Interactive
Marketing, 47, 102-114. doi: 10.1016/j. intmar.2019.02.004

Naderi, A., \& Yazdi, M. H. (2018). An anthropological study on female peddlers' lingual and paralingual advertising in the subway in Tehran. Pertanika Journal of Social Science and Humanities, 26(T), 83-102.

Negm, E., \& Tantawi, P. (2015). Investigating the impact of visual design on consumers' perceptions towards advertising. International Journal of Scientific and Research Publication, 5(4), 1-9.

Nowghabi, A. S., \& Talebzadeh, A. (2019). Psychological influence of advertising billboards on city sight. Civil Engineering Journal, 5(2), 390-397.

Okazaki, S., Mueller, B., \& Taylor, C. R. (2010). Global consumer culture positioning: Testing perceptions of soft-sell and hard-sell advertising appeals between U.S. and Japanese consumers. Journal of International Marketing, 18(2), 20-34.

Shareef, M. A., Mukerji, B., Dwivedi, Y. K., Rana, N. P., \& Islam, R. (2019). Social media marketing: Comparative effect of advertisement sources. Journal of Retailing and Consumer Service, 46, 58-69. doi: 10.1016/j.jretconser.2017.11.001

Steinhart, Y. (2012). All that glitters is not gold: The dual effect of activation technique in advertising. Marketing Letters, 23, 195-208. doi: 10.1007/ s11002-011-9147-0

Struppek, M. (2014). Urban media cultures reflecting modern city development. Screencity Journal, 4, 1-6.

Syah, H. (2013). Urbanisasi dan modernisasi (Studi tentang perubahan sistem nilai budaya masyarakat urban di Pangkalan Kerinci kabupaten Pelawan) [Urbanization and modernization (Study of changes in the cultural value system of urban communities in Pangkalan Kerinci, Pelawan district)]. Toleransi, 5(1), 1-12. 
Tamam, E., Willnat, L., \& Osman, N. (2009). Turhan, B., \& Okan, Z. (2017). Critical discourse Self-construal and exposure to American entertainment and news programs among analysis of advertising: Implications for language Malaysians youths. Pertanika Journal of Social Sciences and Humanities, 17(1), 17-24. teacher education. International Journal of Language Education and Teaching, 5(4), 213226.

Terkan, R. (2014). Importance of creative advertising and marketing according to university students' perspective. International Review of Management and Marketing, 4(3), 239-246. 